\title{
PATOLOGI BIROKRASI DALAM PELAYANAN PENGURUSAN PASPOR DI KANTOR IMIGRASI KELAS 1 KOTA MAKASSAR
}

\section{THE PATHOLOGY OF BUREAUCRACY IN PASSPORT MANAGEMENT SERVICES IN THE CLASS 1 IMMIGRATION OFFICE OF MAKASSAR CITY}

\author{
Eka Fitra Ramadani ${ }^{1}$ \\ Universitas \\ Muhammadiyah \\ Makasssar, Indonesia ${ }^{1}$ \\ email: \\ ekfira@gmail.com

Musliha Karim
Universitas
Muhammadiyah
Makasssar, Indonesia $^{2}$

\section{Burhanuddin ${ }^{3}$ \\ Universitas \\ Muhammadiyah \\ Makasssar, Indonesia ${ }^{3}$}

IJI Publication

p-ISSN: 2774-1907

e-ISSN: 2774-1915

Vol. 1, No. 2, pp. 97-

104 ,

Maret 2021
Abstrak: Banyaknya pengaduan masyarakat berupa pelayanan yang berlarut-larut, mempersulit, diskriminasi pelayanan dan lamanya waktu penyelesaian pelayanan di Kantor Imigrasi Kelas 1 Kota Makassar menunjukkan adanya patologi birokrasi yang terjadi. Oleh karena itu, penelitian ini bertujuan untuk mengetahui patologi yang terdapat dalam pelayanan pengurusan paspor di Kantor Imigrasi Kelas 1 Kota Makassar. Jenis penelitian yang digunakan dalam penelitian ini adalah penelitian deskriptif kualitatif. Tipe penelitian adalah fenomenologis. Teknik pengumpulan data yang digunakan adalah studi pustaka dan studi lapangan (observasi, wawancara, dan dokumentasi). Teknik penentuan informan dengan menggunakan purposive sampling. Hasil penelitian patologi birokrasi dalam pelayanan pengurusan paspor di Kantor Imigrasi Kelas 1 Kota Makassar, menunjukkan masih adanya perilaku negatif dalam hal ini patologi birokrasi dalam memberikan pelayanan seperti, penyalahgunaan wewenang, yang terdiri pemanfaatan kekuasan dan jabatan, dan memperlambat proses penyelesaian. Diskriminasi, seperti perbandingan promordialisme, satu almamater, status sosial, dan status kekeluargaan. Upaya untuk mengurangi terjadinya patologi birokrasi yang terdiri dari: pendisiplinan pegawai, yaitu kehadiran yang tepat waktu, dan menjunjung etos kerja serta peningkatan pengawasan, seperti sumber daya manusia (SDM) yang memadai, dan penerapan budaya organisasi yang optimal.

Kata Kunci: Patologi, Pelayanan, Pengurusan Paspor.

Abstract: The number of public complaints is in the form of protracted services, complication, discrimination of services and the length of time for completion of services at The Class 1 Immigration Office of Makassar City shows a bureaucratic pathology that occurs. Therefore, The purpose of this research to find out the pathology contained in passport processing services at the Class 1 Immigration Office of Makassar City. This type of research used in this research is descriptive qualitative research. The type of research isphenomenological.Data collection techniques used are literature study and field studies (observation, interviews, and documentation). The technique of determining informants using purposive sampling. The results of research on bureaucratic pathology in passport processing services at the Class 1 Immigration Office in Makassar show that there is still negative behavior, in this case the pathology of the bureaucracy in providing services such as,abuse of power, which consists of exploiting power and position, and slowing down the settlement process. Discrimination, such as comparative promordialism, one alma mater, social status, and family status. Efforts to reduce the occurrence of bureaucratic pathologies, which consist of: employee discipline, namely on time attendance, and upholding the work ethic and increasing supervision, such asadequate human resources (HR), and the optimal application of organizational culture.

Keywords: Pathology, Services, Management Of Passport.

\section{PENDAHULUAN}

Konteks perkembangan

ilmu

pengetahuan, pemahaman tentang pengetahuan birokrasi mulai dikenal dengan perkembangan konsep Negara modern. Patologi birokrasi (bureaupathology) adalah himpunan dari perilaku-perilaku yang kadang-kadang disibukkan oleh para birokrat. Fitur dari patologi digambarkan oleh Makhya (2004).

Sikap menyisih berlebihan, pemasangan taat pada aturan atau rutinitas-rutinitas dan prosedur-prosedur, perlawanan terhadap perubahan, dan desakan picik atas hak-hak dari otoritas dan status sedangkan birokrasi ialah alat kekuasaan bagi yang menguasainya dimana para pejabatnya secara bersama-sama berkepentingan dalam kontinuitasnya Nugraha (2007).

Red tape merupakan awal kemunculan dari sebuah patologi dalam pelayanan publik. Red tape disebabkan adanya kecenderungan alami yang terjadi di dalam tubuh dan para birokrat yang tercetak dari rutinitas kegiatan 
mereka sendiri. Birokrasi yang semestinya dapat lebih efesien dalam proses pelayanan publik justru semakin berbelit-belit karena para birokrat dalam melakukan tugasnya sebagai pelayan publik terkesan setengah hati, sedangkan seharusnya menurut Moeljarto, (2001) bahwa birokrasi adalah yang semestinya mencerminkan kepentingankepentingan umum lebih banyak tidak mengindahkan muatan moralitas kemanusiaan, dari pada mengaplikasikannya kedalam realitas pelayanan yang sesungguhnya. Dari sifat inilah kemudian lahir berbagai patologi birokrasi seperti nepotisme, penyalahgunaan wewenang, korupsi dan berbagai patologi birokrasi yang menyebabkan aparat birokrasi di negara berkembang umumnya memiliki kreadibilitas yang rendah, Siagian (1994).

Faktor penyebab patologi birokrasi: kekurangan administrator yang cakap, besarnya jumlah aparat birokrasi, luasnya tugas pemerintahan, anasir tradisional (nepotisme, patrimonial, hirarkis), sentralisasi dan besarnya kekuasaan birokrasi. Implikasi patologi birokrasi sebagai berikut: merugikan birokrasi sendiri (krisis kepercayaan, delegitirnasi sosial), masyarakat, stakeholder, bangsa dan Negara, menghambat tercapainya kemajuan, modernisasi, kesejahteraan, dan memicu kerawanan sosial dan perubahan sistem secara evolusi dan revolusi, Soebhan (2000).

Kemunculan berbagai keluhan dan kritikan mengenai kinerja birokrasi yang memang bukan hal yang baru lagi karena sudah ada sejak dulu. Birokrasi lebih menunjukkan kondisi empirik yang sangat buruk, negatif atau sebagai suatu penyakit yang sangat sulit untuk disembuhkan. Keseluruhan kondisi empirik yang terjadi secara akumulatif telah meruntuhkan konsep birokrasi Hegelian dan Weberian yang mengfungsikan mengkoordinasikan unsur-unsur dalam proses pemerintahan. Kenyataannya untuk mengadakan perbaikan terhadap kinerja pelayanan umum di negeri ini dengan macam-macam persoalan dan penyebab yang sangat bervariasi antara satu dengan yang lainnya, sehingga perlu dicari suatu metode yang mampu menjawab persoalan tadi, guna menentukan prioritas pemerintah, Warella. Y (2007).

Birokrasi dalam keadaan demikian hanya berfungsi sebagai pengendali, penegak disiplin, dan penyelenggara pemerintahan dengan kekuasaan yang sangat besar tetapi mengabaikan fungsi pelayanan masyarakat. Menurut Thoha (2003), patologi birokrasi merupakan penyakit, perilaku negatif, atau penyimpangan yang dilakukan pejabat atau lembaga birokrasi dalam rangka melayani publik, melaksanakan tugas, dan menjalankan program pembangunan.

Pelayanan publik memerlukan pengawasan yang optimal dalam setiap tahapan prosedur yang dijalankan, agar tercipta pelayanan yang efektif dan efisien. Tanpa adanya pengawasan, kinerja para birokrat akan menjadi tidak profesional dan cenderung tidak mengalami perkembangan yang signifikan untuk menjadi bahan evaluasi oleh pemerintah.

Adanya pengawasan yang lebih dapat mengurangi masalah yang terjadi dalam pelayanan publik juga dapat menjadi acuan bagi pihak pemerintah dalam meningkatkan kinerja para birokratnya diberbagai bidang pelayanan publik. Kurangnya pengawasan juga dapat mengakibatkan terjadinya diskriminasi terhadap masyarakat dimana hanya mementingkan pihak-pihak tertentu dan mengabaikan peraturan yang sudah ada, yang berimbas pada pelayanan yang semraut dan tidak teratur.

Sedianya pelayanan publik adalah segala aktivitas yang dilakukan oleh pemerintah maupun swasta yang menghasilkan barang dan jasa, yang ditujukan untuk memenuhi kebutuhan publik, Sjahrir (2001). Kondisi tersebut merupakan 
bentuk ketidak berhasilan kinerja birokrasi dalam upaya menuju good governance. Good governance mempunyai arti sebagai salah satu cara mengatur pemerintahan yang baik dengan memberikan pelayanan publik yang efisien.

Salah satu kapabilitas yang harus dimiliki adalah akuntabilitas yaitu suatu ukuran yang menunjukkan seberapa besar tingkat kesesuaian penyelenggaraan pelayanan dengan ukuran nilai-nilai atau norma eksternal yang ada di masyarakat atau yang dimiliki oleh para stakeholders, Finer (Raba, 2006) menyatakan bahwa akuntabilitas harus formal dan merujuk pada acara kontrol eksternal, yang jelas kedua dimensi tanggung jawab dan akuntabilitas sangat penting bagi pemerintahan yang demokratis.

Persoalan yang timbul saat ini adalah realitas pelaksanaan fungsi pelayanan dibidang pengurusan paspor di Kantor Imigrasi Kelas 1 Kota Makassar. Pengamatan awal peneliti, menunjukkan Kantor Imigrasi Kelas 1 Kota Makassar rawan mal administrasi. Hal ini dilihat dari banyaknya pengaduan masyarakat berupa pelayanan yang berlarut-larut, mempersulit, diskriminasi pelayanan dan lamanya waktu penyelesaian pelayanan.

Fenomena tersebut menunjukkan belum tercapainya akuntabilitas pelayanan publik yang berkaitan dengan proses yang dikarenakan kurangnya pengawasan dalam kinerja para birokrat. Upaya untuk mewujudkan pelayanan yang akuntabel terhadap pengguna jasa, ditetapkan Keputusan Menteri PAN Nomor. 26/KEP/M.PAN/6/2004 tentang Pedoman Umum Penyelenggaraan Pelayanan Publik. Maksud ditetapkannya petunjuk teknis ini adalah sebagai acuan bagi seluruh penyelenggaraan pelayanan publik untuk meningkatkan kualitas transparansi dan akuntabilitas pelayanan termasuk masalah controlling yang harus diperkuat. Maka, menjadi suatu keharusan bagi Kantor Imigrasi Kelas 1 Kota Makassar untuk akuntabel dalam memberikan pelayanan yang bisa memuaskan masyarakat.

Kenyataan inilah yang membuat sebagian masyarakat kehilangan kepercayaan terhadap birokrat pemerintah yang seharusnya mampu menjadi pelayan masyarakat yang mengutamakan kepuasan publik diatas kepentingan pribadi. Berdasarkan latar belakang masalah yang dikemukakan di atas maka peneliti bermaksud untuk mengangkat judul tentang, "Patologi Birokrasi Dalam Pelayanan Pengurusan Paspor dsi Kantor Imigrasi Kelas 1 Kota Makassar".

\section{METODE}

Jenis penelitian yang dilakukan adalah penelitian deskriptif kualitatif yaitu suatu jenis penelitian yang bertujuan untuk memodifikasi data-data yang telah dikumpulkan dilapangan berdasarkan fenomena sosial. Tipe penelitian yang di gunakan dalam adalah penelitian fenomenologis yaitu menggambarkan pengalaman yang dilihat oleh informasi berkaitan dengan koordinasi. Nasution dalam Sugiyono, (2012) menyatakan dalam penelitian kualitatif, tidak ada pilihan lain dari pada menjadikan manusia sebagai instrument dalam penelitian utama. Dalam mengumpulkan data yang diinginkan, sehingga informan yang dipilih adalah para informan yang mampu memberikan informasi yang lebih mendalam mengenai patologi birokrasi dalam pelayanan pengurusan paspor di Kantor Imigrasi Kelas 1 Kota Makassar.

Teknik penentuan informan dengan menggunakan purposive sampling. Analisis data ialah langkah selanjutnya untuk mengelolah data dimana data yang diperoleh, dikerjakan dan dimanfaatkan sedemikian rupa untuk menyimpulkan persoalan yang diajukan dalam menyususn hasil penelitian. 
Teknik analisis data yang digunakan dalam penelitian ini adalah model analisis interaktif Dalam model ini terdapat kompenen pokok.

\section{HASIL DAN DISKUSI}

Berdasarkan hasil penelitian yang diperoleh mengenai patologi birokrasi dalam pelayanan pengurusan paspor di Kantor Imigrasi Kelas 1 Kota Makassar yang dilakukan dengan menggunakan wawancara, observasi dan didukung oleh beberapa dokumen, dimana pertanyaan-pertanyaan yang digunakan dalam bentuk wawancara dan memperoleh respon pertanyaan yang positif dari para informan.

Semakin tingginya jabatan seorang aparat pemerintah ternyata tidak lantas membuatnya mampu bersikap adil dalam pemberian pelayanan masyarakat secara menyeluruh dan tanpa pandang buluh, perilaku pemanfaatan kekuasaan dengan dalih untuk mempercepat proses penyelesaian paspor, yang tentu saja tidak dibenarkan dalam aturan dan tergolong dalam penyalahgunaan wewenang, pelayanan seperti meminta imbalan sebab hal tersebut adalah pemanfaatan jabatan yang hanya akan merugikan tidak hanya masyarakat tapi juga dirinya sendiri.

Dokumen yang salah akan tetap salah meski berusaha disembunyikan sebab semua dokumen akan diproses dengan aplikasi komputer secara otomatis akan memperlihatkan hasil yang sebenarnya, dan sebagai masyarakat yang cerdas juga harus bisa waspada dan ikut mengawasi aparat yang memberi pelayanan dengan memanfaatkan jabatannya, dalam menangani tindakan korup yang dilakukan oleh pegawai yang dengan sengaja memanfaatkan jabatannya harus melibatkan masyarakat dalam membantu mengawasi agar perilaku negatif seperti korupsi bisa diatasi sedini mungkin sebelum merugikan orang lain.

Tidak hanya pemanfaatan kekuasaan yang menjadi bentuk patologi yang terdapat dalam pelayanan pengurusan paspor, ada pula masalah keterlambatan proses penyelesaian, sikap mementingkan diri sendiri dibanding kepentingan masyarakat yang imbasnya membuat tahap penyelesaian paspor menjadi lambat dan tidak sesuai dengan target waktu yang telah disepakati, profesionalitas merupakan bagian yang amat dijunjung tinggi dalam pelayanan masyarakat meski terkadang dalam penyelenggaraannya masih sering ditemui adanya kesulitan yang tidak diketahui oleh masyarakat umum.

Pengurus paspor lain yang dokumennya sempat disimpan untuk diberikan waktu guna melengkapi berkas permohonannya tanpa perlu membawanya kembali sehingga tidak akan merepotkan untuk dibawa kembali, petugas kantor tidak pernah memberatkan masyarakat dengan selalu berusaha memberi pelayanan yang optimal, dimaksudkan agar dokumen yang sudah ada tidak tercecer, setiap tindakan pegawai kantor selalu diandasi dengan alasan yang tidak lain demi kepentingan masyarakat yang akan menerima pelayanan itu sendiri.

Pentingnya keterbukaan suatu birokrasi dalam arti kejelasan peraturan perundangundangan yang menjadi dasar bertindak, agar tidak terjadi perbandingan dalam pemberian pelayanan, terjadinya tindakan diskriminasi yang dengan sengaja lebih mengutamakan kesukuan terhadap pengurus paspor lain ketimbang pengurus paspor yang memang sudah menaati peraturan yang ada dengan sabar mengantri sampai mendapat giliran.

Tindakan diskriminasi yang cukup sulit dihindari meskipun sebenarnya bisa diberikan pengertian kepada sanak keluarga agar bisa menerima sikap profesional dalam bekerja, sebagai masyarakat kita tidak boleh egois dan mementingkan diri sendiri, setidaknya membantu pegawai dalam menjalankan tugasnya dengan baik adalah suatu keharusan jika ingin menuntut keadilan.

Profesionalitas sangat dijunjung meski masih ada sebagian pegawai yang masih sulit 
menerapkannya dengan alasan status orang yang dilayani, semua tahapan dalam proses pelayanan masyarakat di Kantor Imigrasi Kelas 1 Kota Makassar dapat berjalan dengan baik apabila adanya kerjasama antara pegawai kantor yang profesional dengan masyarakat yang sadar akan peraturan yang berlaku dalam ruang lingkup kantor tersebut sehingga terwujud pelayanan yang optimal tanpa merugikan orang lain.

Sama dengan halnya primordialisme yang mendahulukan kepentingan pribadi dalam hal ini satu almamater juga memiliki arti yang sama bahwa hanya yang memiliki teman saja yang mendapat pelayanan khusus, celah diskriminasi dalam pemberian pelayanan hanya dengan alasan karena satu almamater, meskipun sadar betul bahwa tindakan tersebut dapat merigukan orang lain yang sudah mengantri, dapat dijabarkan bahwa sebenarnya masyarakat sendiri yang menjadi alasan mengapa ada perbedaan pelayanan yang terjadi dalam pembuatan pengurusan paspor di Kantor Imigrasi Kelas 1 Kota Makassar.

Adapun kesadaran masyarakat yang memang bisa mengikuti prosedur meski harus mengantri untuk dapat giliran, seharusnya ini bisa menjadi contoh yang baik untuk masyarakat lain, masalah jaringan memang selalu menjadi masalah yang cukup mengganggu ketika pelayanan yang sudah dianggap optimal tapi kembali menuai masalah karena dokumen harus bisa mendapat persetujuan terlebih dahulu dari kantor pusat kemudian bisa mendapatkan ijin untuk mencetak paspor, selama semua dilakukan sesuai prosedur tentu tak akanada masalah, masyarakat itu sendiri yang merugikan orang lain meskipun mereka tahu tindakan tersebut tidaklah benar, sedangkan dari pihak pegawai yang dimintai pertolongan tentu berasumsi bahwa siapa saja yang minta pertolongan jelas harus dibantu tanpa pandang buluh.
Penyakit satu ini adalah penyakit yang paling sering ditemukan dalam proses pelayanan masyarakat dan paling mendapat sorotan terbanyak, protes atas ketidakadilan yang dirasakan oleh salah satu pengurus paspor yang sebenarnya sudah bertindak benar dengan mengantri sesuai nomor urutnya, namun akhirnya kecewa karena adanya oknum pengurus paspor yang tidak ingin ambil pusing dengan menyerobot masuk tanpa perlu antri dan sudah pasti menyalahi aturan, hal tersebut mungkin bisa menjadi teguran kepada pihak kantor, apabila memang berniat agar pelayanan bagi orang yang memiliki status sosial tinggi butuh pelayanan yang ekstra maka mereka pun harus punya loket sendiri tanpa perlu ikut mengantir berlama-lama atau bahkan merugikan orang lain.

Fungsi pegawai memang tidak hanya sebagai pelayan masyarakat tetapi juga bisa menjadi pengawas bagi pegawai lain untuk menghindari perilaku negatif, penyakit status sosial adalah masalah yang secara tidak langsung sudah menjadi budaya dalam pelayanan masyarakat, yang selalu dipandang biasa saja bagi para aparat birokrat padahal sama sekali tidak memiliki sisi positif cenderung merugikan masyarakat lain, dan seharusnya pegawai harus lebih teliti tidak hanya kepada masyarakat yang dilayani tetapi juga kepada pegawai lain yang memberi pelayanan.

Diantara banyak masalah diskriminasi, mungkin status kekeluargaan yang menjadi penyumbang terbanyak setelah status sosial, sebab penyakit ini paling sensitif untuk dijabarkan. Meskipun pada teori profesionalitas tidak mengenal kata keluarga tapi dalam realita berkata lain, masyarakat berpikir bahwa dengan adanya bantuan dari anggota keluarga yang menjadi patokan saat ingin mengurus sesuatu dilingkungan kantor Imigrasi khususnya, bisa lebih mempermudah tanpa melewati birokrasi yang panjang meskipun disisi lain tentu saja tetap 
merugikan orang lain dan menyalahi aturan yang sudah ada.

Ada pegawai yang memang dengan sengaja memakai status kepegawaiannya untuk memberi jalan agar keluarganya bisa lebih didahulukan dari masyarakat lain yang sedang mengurus paspor, namun dengan tidak langsung menemani, ada kalanya pertolongan bisa diberikan jika sanak keluarga menemui kesulitan yang mungkin tidak bisa ditangani sendiri bukan meminta tolong untuk mempercepat pembuatan paspor dengan memakai tameng kekeluargaan dengan pegawai kantor.

Kehadiran yang tepat waktu dapat membuat pelayanan menjadi lebih cepat dan terwujudnya pencapaian target kewajiban sebagai pegawai, pegawai yang ditunjuk seharusnya disiplin waktu agar tidak mengakibatkan pengurus paspor jadi menumpuk dan terus menunggu lama, setiap pelanggaran perturan yang dilakukan oleh pegawai Kantor Imigrasi Kelas 1 Kota Makassar akan selalu mendapat peringatan langsung dari atasan dan ditindak secara tegas agar kedisiplinan pegawai tetap terjaga dan bisa menjadi panutan tidak hanya dikalangan sesama pegawai tetapi juga menjadi contoh bagi masyarakat luas, nomor antri sengaja dibagi langsung oleh satpam guna menghindari hal-hal yang tidak diinginkan seperti masyarakat yang sengaja mengambil beberapa nomor antrian untuk orang lain dan bisa saja pada saat itu mesin tersebut sedang tidak bisa berfungsi dengan baik.

Sebagaimana diketahui bahwa etos kerja merupakan etika atau perilaku yang dilakukan dalam pekerjaan yang memiliki nilai tersendiri, khususnya pada bagian pelayanan pengurusan paspor di Kantor Imigrasi Kelas 1 Kota Makassar, pegawai yang bertugas seharusnya bisa menerapkan senyum, salam, dan sapa kepada masyarakat yang dilayani sehingga masyarakat merasa bukannya merasa segan tapi akhirnya menjadi takut, ternyata sikap yang dinilai galak oleh masyarakat adalah sikap tegas yang memang diharuskan untuk mengetahui keaslian data dan dokumen pengurus paspor.

Kecurigaan memang selalu ada agar pegawai tidak mudah dikelabui, sebab memberikan ijin kepada seseorang berarti memberikan tanggung jawab pula, itulah alasan mengapa sikap tegas sangat wajib dipakai dalam mewawancarai pengurus paspor, tapi sebelum memasuki tahap wawancara juga sudah dilakukan wawancara nonformal dari pegawai dibagian loket perijinan, alasan yang tertera dilembaran permohonan harus sinkron dan tidak boleh dibuat-buat apalagi sampai dipalsukan karena itu dianggap melanggar hukum, agar tidak timbul kecurigaan yang bisa membuat perijinan sulit didapat.

Sumber daya manusia dapat diartikan sebagai subjek sekaligus objek yang sangat menentukan keberhasilan suatu program dan rencana yang dibuat oleh suatu organisasi dalam mencapai tujuan dan jika sumber daya yang ada justru kurang, malah akan menimbulkan masalah dalam pemberian pelayanan, kurangnya personil pegawai di kantor memaksakan pegawai lain yang tidak memiliki wewenang harus menutupi kekurangannya dengan menggantikannya sementara waktu, padahal itu sudah menyalahi aturan bahwa setiap pegawai memiliki wewenang dan tanggung jawabnya masing-masing.

Pegawai dikatakan lalai apabila dalam memberikan pelayanan menyebabkan masyarakat menjadi tidak nyaman bahkan berakibat tidak ingin mengurus paspor di kantor itu lagi, memang sudah disediakan loket informasi bagi masyarakat yang ingin tahu lebih jelas dengan tahapan yang akan dilalui untuk mendapatkan paspor atau ingin tahu persyaratan apa saja yang harus dilengkapi dalam pembuatan paspor, satpam juga bisa melayani masyarakat tidak hanya untuk mengamankan kantor semata bahkan 
satpam memang kadang menutupi kekurangan personil pegawai juga.

Kekurangan pegawai juga diakibatkan adanya penugasan ditempat lain yang mengharuskan pegawai tersebut digantikan oleh pegawai lain, penggunaan satpam ditempat pegawai lain bukan tanpa alasan atau dianggap melalaikan tugas tetapi hal ini diperuntukkan agar masyarakat lebih nyaman dan tidak bingung mencari informasi juga tidak mengurangi fungsi pegawai itu sendiri.

Setiap orang akan berperilaku sesuai dengan budaya yang berlaku agar diterima di lingkungannya. Kepribadian seseorang akan dibentuk pula oleh lingkungannya dan agar kepribadian tersebut mengarah kepada sikap dan perilaku yang positif tentunya harus didukung oleh suatu norma yang diakui tentang kebenarannya dan dipatuhi sebagai pedoman dalam bertindak, sulitnya mengontrol pegawai yang kurang menerapkan budaya yang sudah ajarkan, tidak hanya budaya untuk mengoptimalkan pelayanan tapi juga budaya lain seperti patuh terhadap atasan dan semua peraturan yang mengikat mereka sebagai pelayan masyarakat.

Memberi peringatan juga kepada masyarakat agar lebih waspada dengan tindakan pegawai diluar prosedur seperti meminta imbalan agar prosesnya lebih cepat, dengan menjaga setiap perilaku dalam memberikan pelayanan tentu bisa menjadi kebanggan tersendiri tidak hanya untuk pimpinan tetapi juga seluruh pegawai, sebab penilaian masyarakat sebenarnya hanya bermuara pada satu perilaku pegawai yang bisa dijadikan gambaran bagaimana sikap pegawai yang lainnya.

Dalam meningkatkan budaya organisasi memerlukan cara yang tidak mudah, kembali memerlukan pengawasan agar perilaku negatif bisa dihilangkan juga pengaruh lingkungan menjadi aspek penting untuk peningkatan kualitas kerja yang memerlukan contoh dari pimpinan agar menjadi acuan bagi bawahan dan pegawai lainnya.

\section{KESIMPULAN}

Berdasarkan hasil penelitian mengenai patologi birokrasi dalam pelayanan pengurusan paspor di Kantor Imigrasi Kelas 1 Kota Makassar, menunjukkan masih adanya perilaku negatif dalam hal ini patologi atau penyakit yang ditemukan dalam memberikan pelayanan seperti, bentuk patologi yang ditemukan dalam pelayanan pengurusan paspor terdiri dari: penyalahgunaan wewenang, yang terdiri pemanfaatan kekuasan dan jabatan, dan memperlambat proses penyelesaian. Diskriminasi, seperti perbandingan promordialisme, satu almamater, status sosial, dan status kekeluargaan. Upaya untuk mengurangi terjadinya patologi birokrasi yang terdiri dari: pendisiplinan pegawai, yaitu kehadiran yang tepat waktu, dan menjunjung etos kerja. Peningkatan pengawasan, seperti sumber daya manusia (SDM) yang memadai, dan penerapan budaya organisasi yang optimal. Hasil ini didapat berdasarkan pengalaman pengurus paspor dan dari hasil pengamatan saat penelitian berlangsung, meski ada pula beberapa hasil pengalaman tersebut yang bertentangan dengan hasil pengamatan dilapangan. Sehingga dapat disimpulkan bahwa pelayanan pengurusan paspor di Kantor Imigrasi Kelas 1 Kota Makassar, masih terdapat penyakit birokrasi yang menjadi keluhan masyarakat tetapi selalu berusaha untuk dihilangkan oleh pihak kantor Imigrasi demi terus mewujudkan pelayanan yang baik kepada masyarakat.

\section{REFERENSI}

Keputusan Menteri PAN Nomor. 26/KEP/M.PAN/6/2004 tentang Pedoman Umum Penyelenggaraan Pelayanan Publik. 
Makhya, Syarief. (2004). Ilmu Pemerintahan -

Telahaan Awal. Jurusan Ilmu

Pemerintahan Fisip UNILA. Lampung:

Buku Ajar.

Moeljarto, Tjokrowinoto. (2001). Birokrasi dalam Polemik. Malang: Pusaka Pelajar.

Raba, Manggaukang. (2006). Akuntabilitas Konsep dan Implementasi. Malang: UMM Press.

Safri, Nugraha. (2007). et al. Hukum Administrasi Negara. Depok: CLGSFHUI.

Siagian, P. Sondang. (1994). Patologi Birokrasi, Analisis, Identifikasinya dan Terapinya. Jakarta: Ghalia Indonesia.

Sjahrir. (2001). Kebijakan Negara: Konsistensi dan Implementasi. Jakarta: LP3ES.

Sugiyono. (2008). Metode Penelitian Kuantitatif Kualitatif $R \& D$. Bandung: Alphabeta.

Soebhan, Syafuan Rozi. (2000). Model Reformasi Birokrasi di Indonesia. Jakarta: LIPI.

Thoha, Miftah. (2003). Birokrasi dan Politik di Indonesia. Jakarta: Raja Grafindo.

Warella Y. (2007). Pergeseran Paradigma Administrasi Publik. Semarang: Loka Karya Kurikulum Berbasis Kompetensi. 